Available online at: http://e-journal.upstegal.ac.id/index.php/jip

Submission : 28-08-2018; Revision: 14-10-2018; Publish Date: 30-10-2018

DOI : $10.24905 /$ jip.v2i2.1007

\title{
Governansi Publik Model Co-Production Oleh Aktor Socio-Preneur (Kasus Desa Setanggor Dan Kawis Krisant)
}

\author{
Evi Sukmayeti1) *, Vidya Yanti Utami2) \\ 1Program Studi Ilmu Administrasi Negara, STIA Mataram. Jalan Bung Karno No.60, Pagesangan, \\ Kota Mataram, Nusa Tenggara Barat 83127 Indonesia. \\ 2 Program Studi Ilmu Administrasi Negara, STIA Mataram. Jalan Bung Karno No.60, Pagesangan, \\ Kota Mataram, Nusa Tenggara Barat 83127 Indonesia \\ * Korespondensi Penulis. E-mail:evi.sukmayeti@gmail.com, Telp: +6281917122187
}

\begin{abstract}
Abstrak
Keterbatasan pemerintah, baik dari sisi kapasitas pelayanan dan pengelolaan anggaran publik, membuka ruang dimana dibutuhkan pembaharuan peran pembangunan. Lahirnya wirausahawan sosial di Indonesia, tak ubahnya seperti aktivitas kebijakan negara yang dapat dikategorikan dalam berbagai bidang kehidupan masyarakat, sekalipun keduanya tidak terpisah satu sama lain. Analisis terhadap dua kasus wirausaha sosial, Desa Setanggor dan Kampung Wisata Krisant, dengan beberapa konsep mutakhir peran non-pemerintah dalam pembangunan khususnya konsep co-production diharapkan mampu menjadi memperkaya pemecahan persoalan publik. Artikel ini merupakan intisari dari penelitian terhadap inisiatif 2 (dua) orang socio-preneur yang dianggap mewakili keberhasilan aktor non-pemerintah dalam konteks governansi publik yang berbeda. Kedua inisiatif pembangunan tersebutberjalan efektif dengan mengandalkan kontribusi modal sosial yang ada di sekitar mereka, saling timbal balik, dan secara berkelanjutan memproduksi barang dan jasa yang bernilai ekonomis sehingga kesejahteraan sosial komunitas dan warga dapat dilihat sebagai dampaknya.
\end{abstract}

Kata kunci: Governansi Publik, Co-Production, Socio-preneur.

\section{Public Governance Using Co-Production Model Through Socio-Preneur Movement (Case Of Setanggor Village and Kawis Krisant)}

\begin{abstract}
The limitations of government, both in the capacity of public services and budget management, created space tothird actor contribution in development. The emerging of social entrepreneurs in Indonesia, being categorized in many different areas of public life, connected to governmental policy. Analysis of two case of social entrepreneur, Setanggor Village and Kawis Krisant, usingnongovernmental role in development concept particularly the concept of co-production is expected as enrichment of public probles solving. This article extractedfrom research reporting conducted to two initiative of successful socio-preneur in the context of a public governance. Both initiatives were effective established rely on the contribution of existing social capital surround, mutual reciprocity, and sustainable production on goods and services. Consequentlycommunity and residents social welfare was perceived as its effects.
\end{abstract}

Keywords: Public Governance, Co-Production, Socio-preneur. 
Jurnal Ilmu Pemerintahan: Kajian Ilmu Pemerintahan dan Politik Daerah, 3 (2),

Oktober 2018 - 121

Evi Sukmayeti1) *, Vidya Yanti Utami²)

\section{PENDAHULUAN}

Keterbatasan pemerintah, baik dari sisi kapasitas pelayanan dan pengelolaan anggaran publik, membuka ruang dimana dibutuhkan pembaharuan peran pembangunan. Indonesia belum bisa terlepas dari pengalaman tersebut. World Economic Forum (WEF) melakukan studi terhadap beberapa negara di dunia pada tahun 2017 terkait pembangunan dan inklusifitasnya (World Economic Forum, 2017). Indonesia termasuk di dalam daftar negara yang dijadikan responden oleh WEF. Laporan The Inclusive Growth and Development Report memuat beberapa hal cukup menggembirakan jika dibaca dari hasil studi WEF ini, salah satunya bidang pendidikan dimana negara kita dinilai memiliki sistem edukasi yang cukup kuat namun belum mencapai ke seluruh siswa. Namun dari sisi fasilitas umum dan ketenagakerjaan, WEF menempatkan Indonesia pada peringkat bawah (World Economic Forum, 2017) karena memang pekerjaan rumah terbesar negara dengan jumlah penduduk tambun seperti kita adalah terkait penyediaan fasilitas dan lapangan pekerjaan tersebut

Dukungan perbaikan dari sisi pendidikan pun ironinya dipandang masih belum mampu menciptakan masyarakat warga yang baik. Hans Antlov dalam kata pengantarnya bahkan menyebutkan bahwa jika masyarakat warga yang hanya terdiri dari para intelektual UI, UGM dan ITB adalah masyarakat warga yang payah (Zakaria, 2004;16). Kritiknya tersebut ia sampaikan sebagai dasar argumennya bahwa orang-orang desa harus mampu menguasai kembali arena hidupnya sendiri dengan menentukan kehidupannya sesuai jalan yang dipilihnya mereka sendiri. Kedua tokoh terakhir ini lebih dalam memperbincangkan pembangunan di pedesaan dimana Indonesia memang dibangun secara historis dan geografis oleh daerah-daerah desa.

Di sisi lain, iklim pendidikan yang lebih baik melahirkan kesadaran warga akanadanya kekurangan didalam pelaksanaan pembangunan yang diperankan oleh pemerintah. Kritik hingga usaha sosial, yang bersinergi hingga berupaya 'menggantikan' peran negara lahir dalam bentuk wirausaha sosial memberikan harapan besar bagi kolaborasi negara dan aktor di luarnya dalam membangkitkan potensi masyarakat agar bermanfaat bagi mereka sendiri.Sayangnya hingga artikel ini selesai ditulis, belum didapatkan basis data yang memadai terkait angka perkembangan wirausahawan sosial di Indonesia, selain informasi kasusistik mengenai bentuk dan aktor penggerak wirausaha sosial tersebut di beberapa wilayah. Penelusuran penulis terhadap beberapa kasus wirausaha sosial dan permasalahan publik yang menjadi target pemecahannya adalah individu atau kelompok masyarakat yang mengorganisasi kegiatan pembangunan dalam skala yang lebih kecil untuk melengkapi program yang dilakukan oleh pemerintah. Pada tahap ini inisiator pelaksanaan pembangunan masyarakat tidak lagi dimonopoli oleh pemerintah ataupun dunia usaha melalui program corporate social responsibility-nya.

Lahirnya wirausahawan sosial di daerah-daerah di Indonesia, tak ubahnya seperti aktivitas kebijakan negara yang dapat dikategorikan dalam berbagai bidang kehidupan masyarakat, sekalipun tidak terpisah satu sama lain. Ada wirausahawan sosial yang lahir dan 


\section{Jurnal Ilmu Pemerintahan: Kajian Ilmu Pemerintahan dan Politik Daerah, 3(2), Oktober 2018- 122 \\ Evi Sukmayeti1) *, Vidya Yanti Utami²)}

bertindak dalam bidang lingkungan namun berkembang dalam lingkup pariwisata. Atau wirausahawan sosial lainnya memulainya dari kegiatan ekonomi yang memberdayakan perempuan, namun dalam perkembangannya memperluas dampaknya di bidang pendidikan bahkan politik. Di Nusa Tenggara Barat, belum tersedia basis data wirausaha sosial selain buku-buku, jurnal, laporan dan berita tentang sosok kasuistik wirausaha sosial sukses yang memotivasi dan menginspirasi. Bisa jadi ini dikarenakan tokoh-tokoh tersebut memang tidak mengutamakan pencitraan dibandingkan gerakan atau itu sendiri.

Dalam artikel ini, penulis memaparkan dua kasus wirausaha sosial dan menerapkan analisis dengan beberapa konsep mutakhir peran non-pemerintah dalam pembangunan khususnya konsep co-production yang dipandang sebagai konsep yang lebih baik dibandingkan partisipasi masyarakat dalam memecahkan persoalan publik. Desa Setanggor di Lombok Tengah, sebagai desa destinasi wisata baru di Nusa Tenggara Barat, berkembang tidak bisa terlepas dari kiprah Ida Wahyuni dalam membangun inisiatif dan membina gerakan warga dalam menyiapkan diri terhadap kunjungan wisatawan. Sementara Kawis (Kampung Wisata) Krisant, sekalipun berlokasi di tengah Kota Mataram, berhasil menarik minat wisatawan lokal dan mancanegara dikarenakan keunikan dan berbagai kemasan produk pertunjukan yang mereka miliki. Kawis Krisant berkembang bukan dimulai dari inistiatif socio-preneur sorang perempuan bernama Aisyah yang langsung tertuju pada bidang wisata, namun diawali dari keprihatinannya terhadap sampah dan isu lingkungan. Kini Desa Setanggor dan Kawis Krisant berhasil membawa perubahan terhadap lingkungan fisik dan sosial serta berdampak pada kesejahteraan ekonomi masyarakat. Bahkan dalam aktivitas mereka, jaringan kegiatan yang terlibat tidak hanya terbatas di wilayah sekitar, namun juga meluas pada wilayah dan kelompok lain.

Prinsip-prinsip

co-production systems yang berhasil dikembangkan oleh masyarakat dalam mengatasi permasalahan publik yang mereka hadapi, di luar campur tangan pemerintah, diinisiasi sendiri melalui komunitas ataupun sociopreneur secara spesifik sebagai motor penggerak, menjadi bahasan menarik. Selain memberikan gambaran aspek orientasi kesejahteraan yang berbeda terhadap orientasi laba, dalam konteks pembangunan ekonomi, keterhubungan kedua konsep ini akan memberikan perspektif yang lebih luas tentang bagaimana peran aktor non-pemerintah dan bagaimana upaya yang mereka lakukan agar co-production systems tersebut berjalan secara efektif.

Penelusuran terhadap kajian terdahulu, umumnya belum sampai mengeksplorasi socio-preneurship dalam konteks governansi publik. Menurut (Yaumiddin, 2013) misalnya, dalam mengeksplorasi socio-preneurship menginterpretasikan Badan Usaha Milik Negara (BUMN) sebagai obyek penelitian melalui program corporate social responsibility (CSR) sebagai fenomena yang mewakili socio-preneurship dikarenakan dalam kegiatannya, BUMN mengadopsi konsep socio-preneurship itu sendiri. Yaumiddin belum sampai pada analisis yang mengkaitkan socio-preneurship pada fenomena yang lebih luas lagi yakni governansi publik. Begitu pula menurut (Saragih, 2017), barangkali dengan latarbelakang 
Jurnal Ilmu Pemerintahan: Kajian Ilmu Pemerintahan dan Politik Daerah, 3 (2),

Oktober 2018 - 123

Evi Sukmayeti1) *, Vidya Yanti Utami ${ }^{23}$

penelitian di bidang ekonomi, hanya mengungkapkan beberapa konseptualisasi dari kewirausahaan sosial dan memberikan studi kasus yang focus pada identifikasi konsep-konsep yang diangkat pada kajian kepustakaan. Penelitianpenelitian lain yang menggunakan konsep governansi publik serta co-production system pun masih sulit ditemukan publikasinya di Indonesia, terlebih dikaitkan dengan fenomena sociopreneurship. Dengan demikian, artikel ini diharapkan menjadi salah satu dasar rujukan artikel pendahuluan yang mendasari penelitian lain yang mengkaitkan fenomena sosial, ekonomi dan khususnya administrasi publik dan pemerintahan dengan konteks governansi publik dan socio-preneurship.

\section{Socio-preneur: Siapa dan Apa yang dilakukan?}

Anggota masyarakat/aktor non pemerintah memegang peranan penting sebagai pilar demokrasi yang mewujudkan masyarakat yang kuat dan mampu memperjuangkan hak-hak rakyat dalam kehidupan bernegara. Aktor non pemerintah seperti ini merupakan individu/kelompok yang secara suka rela bertujuan untuk mendukung dan menopang aktivitas atau kepentingan publik tanpa bermaksud mengambil keuntungan finansial. Dalam bidang ilmu sosial, eksistensi aktor-aktor seperti ini salah satunya memunculkan konsep sociopreneur.

Socio-preneur secara sederhana dapat dipahami sebagai seseorang yang mengerti permasalahan dan menggunakan kemampuan enterpreneurship-nya untuk melakukan perubahan sosial (social change), terutama meliputi bidang kesejahteraan (welfare), pendidikan dan kesehatan (Santosa, 2007). Ini sejalan dengan yang dijelaskan oleh (Dees, 2001) bahwa socio-preneurship merupakan bangunan kombinasi dan semangat besar dalam misi sosial yang diiringi dengan kedisiplinan, inovasi, dan keteguhan seperti yang lazim berlaku di dunia bisnis, bahkan berpikir kritis (Listyorini, 2012). Dalam penjelasan sistematis, (Hulgard, 2010) merumuskan pemikiran sederhana mengenai konsep socio-preneur tersebut sebagai berikut.

\section{Gambar 1.}

Empat Elemen Utama Socio-preneurship menurut Hulgard.

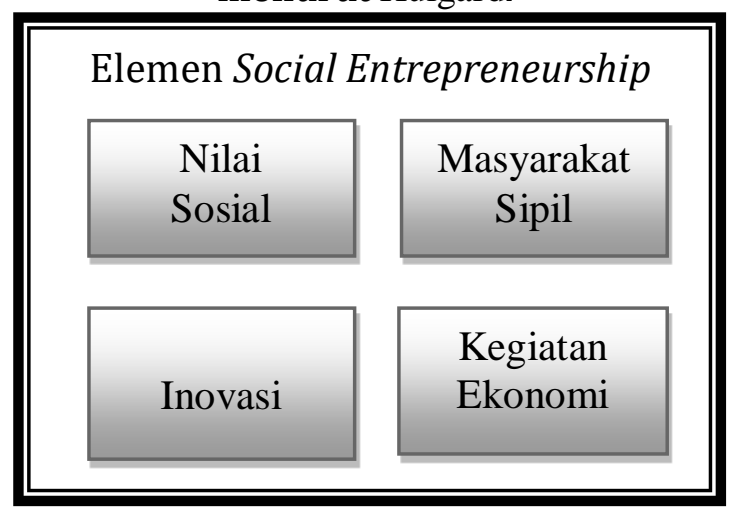

Dengan demikian, batasan tersebut menghubungkan antara spirit bisnis dalam domain publik. Keterkaitan ini membuktikan sejumlah konsep harapan baru dalam bidang administrasi publik atau pemerintahan yang berkembang beberapa dekade terakhir dimana muncul kesadaran akan kurang ampuhnya alat negara yakni pemerintah sebagai aktor tunggal dalam memecahkan persoalan publik.

Seorang socio-preneur biasanya tidak memiliki batas bidang apa yang mereka pilih untuk berperan. Bahkan keberadaanya dapat dibedakan dengan peran pemerintah yang diturunkan dalam bidang-bidang pembangunan yang spesifik seperti kesehatan, pendidikan, infrastruktur, ekonomi dan sebagainya. Sementara socio-preneur bergerak berfokus pada tujuan atau idealismenya 


\section{Jurnal Ilmu Pemerintahan: Kajian Ilmu Pemerintahan dan Politik Daerah, 3(2), Oktober 2018- 124 \\ Evi Sukmayeti1) *, Vidya Yanti Utami ${ }^{2)}$}

sebagaimana dapat dipahami dari batasan-batasan yang dijelaskan di atas. Seorang socio-preneur dapat mengawali kiprahnya di bidang sosial pendidikan, namun dalam perjalanannya mampu merambah sisi ekonomi komunitas bahkan warga. Modal sosial merupakan sumberdaya penting bagi mereka. Dukungan anggota komunitas, jaringan kegiatan hingga aktor di luar masyarakat seperti pihak swasta menjadikan aktivitas mereka berjalan dengan baik dan berkelanjutan. Untuk mencapai tujuan dan mempertahankan idealisme yang mereka miliki, socio-preneur menjadi aktor yang fleksibel dan biasanya cepat dalam berinovasi. Hal ini karena dasar semangat bisnis yang umumnya dimiliki secara riil berhadapan dengan pasar. Nilai tambah pun dapat diidentifikasi dari aktivitas mereka. Idealisme berupa perubahan sosial ke arah yang lebih baik, secara ekonomi dapat diukur sebagai output dan dampak dari aktivitas mereka.

Dalam bidang administrasi publik maupun pemerintahan dan ilmu sosial secara umum, aktivitas socio-preneur sering dikaitkan dengan pemberdayaan. Sejatinya, diskusi-diskusi mengenai pemberdayaan muncul sebagai akibat dari strategi pembangunan yang dinilai gagal sehingga digantikan oleh kesadaran akan pembangunan yang berdimensi social (Calves dalam Sanrego \& Taufik, 2016;64). Socio-preneur memainkan perannya di situ. Modal sosial sebagaimana dijelaskan dalam (Hulgard, 2010), menjadi bahan bakar bagi mesin gerakan dan program yang mereka jalankan. Modal sosial yang tadinya pasif, menjadi bergerak aktif dan menciptakan perubahan sosial dan nilai tambah sosial dan ekonomi. Bahkan lahirnya socio-preneur dan inovasi sosial secara politik diakui oleh Inggris sebagai alternatif tata kelola pemerintahan yang tradisional (Bekkers, Tummers, \& Vooberg, 2013;2)

\section{Governansi Publik Melalui Co- production Systems: Definisi, Prinsip dan Efektivitasnya.}

Konsep pembangunan partisipatif sudah sejak lama dipandang sebagai konsep yang paling pas dengan masyarakat warga di dunia.Menurut konsep ini, inisiatif pelaksanaan pembangunan telah mulai bersumber dari bawah ke atas dan sering pula muncul tokoh-tokoh pembangunan dari kelompok masyarakat. Istilah yang sering digunakan untuk pendekatan pembangunan ini adalah bottom-up approach dan grassroot approach. Perubahan penting di dalam perencanaan dan pelaksanaan pembangunan dengan pendekatan ini terutama adalah terlibatnya anggota masyarakat sebagai pengambil keputusan. Pelaksanaan pembangunan tidak selalu ditentukan oleh program pemerintah. Tidak jarang, masyarakat di tingkat lokal mengkoordinasi sendiri pelaksanaan pembangunan di daerahnya.

Dalam dunia akademik, gejala tersebut disadari berkembang beriringan dengan kenyataan semakin berat dan tidak mungkinnya negara berjalan sendiri dalam pembangunan. Adalah terlalu riskan untuk memandang bahwa pemerintah adalah sosok yang sempurna untuk menyediakan fasilitas publik dan swasta merupakan aktor yang efisien (Pamuji, et al dalam Pratikno, 2007;90) dalam menyediakan pelayanan publik. Ini sepertihalnya yang disadari oleh kaum intelektual Amerika Serikat sejak tahun 1970-an di antaranya Brandson dan 
Jurnal Ilmu Pemerintahan: Kajian Ilmu Pemerintahan dan Politik Daerah, 3 (2),

Oktober 2018 - 125

Evi Sukmayeti1) *, Vidya Yanti Utami²)

Pestoff dimana mereka mengawali preskripsi mereka mengenai konsep coproduction ketika menyadari mitos anggapan satu produsen layanan publik saja yang bertanggungjawab dalam memberikan layanan dan menemukan bahwa ada aktor di luar institusi swasta yang mampu menyediakan layanan dengan respon yang lebih cepat (Putra, 2012;67).

Kelahiran konsep-konsep baru dalam administrasi publik yang dilatorbelakangi oleh kesan mengecilnya kemampuan negara dalam memecahkan persoalan publik, menjadi jembatan preskripsi akademik mengenai pola yang lebih efektif yang dapat dipilih sebuah bangsa dalam pembangunan. Salah satu turunan konseptual yang penting untuk dipahami oleh masyarakat akademik adalah konsep co-production system. Konsep ini bukan konsep baru di kalangan negara maju. Kesiapan aktor nonpemerintah dalam terlibat menyediakan layanan publik diikuti dengan kenyataan bahwa masyarakat sebagai konsumen kebijakan publik pun dapat menjadi produsen bagi diri mereka sendiri.

Jejaring tata kelola pemerintahan baru, yang dikemas dalam rumusan new public governance atau governansi publik baru, diderivasi salah satunya dalam bentuk co-production system. Beberapa alasan dibalik berkembangnya konsep ini adalah (1) kebutuhan akan pembaharuan kualitas layanan publik yang disediakan melalui keahlian pengguna dan jaringan yang mereka miliki, (2) kebutuhan akan layanan yang ditargetkan dengan lebih baik dan lebih responsive, (3) kemungkinan penghematan biaya melalui konsep coproduction dan kesempatan untuk mensinergikan pemerintah dan masyarakat sipil dengan dampak positifnya terhadap modal sosial yang ada (Sicilia, et al 2016;9).

Secara sederhana co-production system merujuk pada tatanan dimana warga negara memproduksi layananlayanan mereka sendiri setidaknya untuk sebagian (Putra, 2012;68). Mereka tidak sekedar berpartisipasi atau ikut dalam menjalankan gagasan-gagasan negara melalui kebijakan publik, namun lebih luas menjadi produsen bagi layanan publik dimana fasilitas dan layanan publik layaknya barang atau jasa mereka ciptakan, adakan dan sediakan untuk diri mereka sendiri, sesuai dengan keinginan dan sumberdaya yang tersedia dan bisa mereka manfaatkan.

Prinsip co-production system yang penting terkait lahirnya socio-preneur di antaranya membangun kemampuan yang ada dari orang-orang dan bekerja dengan dukungan jaringan pribadi disamping jaringan profesional. Ia dapat berjalan efektif layaknya kemitraan yang efektif atas dasar nilai: (1) setiap orang memiliki sesuatu untuk berkontribusi, (2) penting adanya timbal balik, (3) pentingnya hubungan sosial seperti jejaring sosial, terutama keluarga dan komunitas, sangat penting untuk mencapai beberapa jenis perubahan dan (4) kontribusi sosial, bukan kontribusi keuangan (Horne \& Shirley, 2009 slide no. 12) namun kontribusi sosial tersebut dapat berupa waktu, kemauan, keahlian dan upaya yang mereka kontrol sendiri untuk mencapai idealism yang mereka tuju. Sementara pendapat yang berbeda dirumuskan oleh Provan dan Milward mengenai alternatif metode untuk mengevaluasi efektifitas jejaring dalam co-production systems ini yakni 3 (tiga) level analisis pada 


\section{Jurnal Ilmu Pemerintahan: Kajian Ilmu Pemerintahan dan Politik Daerah, 3(2), Oktober 2018- 126 \\ Evi Sukmayeti1) *, Vidya Yanti Utami ${ }^{2)}$}

komunitas, jejaring dan partisipanpartisipan di dalam organisasi jejaring tersebut (Putra, 2012; 242).

\section{METODE}

Artikel ini merupakan intisari dari penelitian kualitatif terhadap inisiatif 2 (dua) orang socio-preneur yang dianggap mewakili keberhasilan aktor nonpemerintah dalam konteks permasalahan publik yang berbeda. Penelitian yang mendasari artikel ini dikategorikan sebagai penelitian kualitatif dikarenakan proses pengumpulan data dan analisis data melibatkan kegiatan wawancara dan observasi sebagai 'meat and potato' dalam kegiatan penelitian kualitatif (Bernard, 2006) dan kegiatan klasifikasi serta interpretasi terhadap data visual dan linguistic (Flick, 2013) yang diperoleh sehingga menghasilkan kesimpulan mengenai governansi publik yang dibangun dalam kedua kasus yang diteliti.

Data diperoleh dari serangkaian wawancara, observasi dan kajian terhadap data sekunder yang tersedia. Wawancara dilakukan terhadap kedua tokoh sentral inisiator dan sejumlah individu yang terhubung dalam jaringan kedua tokoh dalam aktivitas intinya. Sementara observasi dan kajian terhadap data sekunder diterapkan terhadap lingkungan fisik sekitar desa atau kampung wisata, sumberdaya aktivitas mereka dan dampak yang dihasilkan dari kegiatan yang dilakukan oleh kedua sociopreneur bersama komunitas dan jejaringnya. Selain itu (Bernard, 2006) memberikan panduan dalam bidang sosial (terutama antropologi), pengambilan data melalui 'listening and watching' akan bermuara pada produk catatan deskriptif yang menjadi salah satu bagian pokok dalam penelitian kualitatif. Ia juga mengatakan bahwa catatan deskriptif akan paling baik dilakukan bersama orang (peneliti) lain yang juga ingin mempelajari fenomena yang sama. Penelitian ini dilakukan oleh tim dengan dua orang peneliti dan obyek yang berbeda. Keduanya mengenai fenomena sociopreneur dalam konteks pembangunan desa wisata.

Penelitian diawali dengan menentukan sampling socio-preneur yang sukses secara purposif. Sebagai daerah destinasi wisata penting di Indonesia, pulau Lombok diperkaya oleh keberadaan aktivitas socio-preneneurdi bidang pariwisata. Kedua orang socio-preneneur ini bergerak pada basis kegiatan yang berbeda, salah seorang berbasis kegiatan bisnis budaya dan pertunjukan dan seorang lainnya berbasis lingkungan.

Bentuk data yang diperoleh berupa catatan wawancara, catatan observasi, dokumen pribadi kedua socio-preneur, foto-foto dan dokumen publik lainnya seperti berita media massa. Peneliti mengagendakan beberapa kunjungan dan interaksi denga kedua tokoh untuk mendapatkan informasi yang mendukung dicapainya kesimpulan.

Diskusi terhadap hasil penelitian menggunakan pendekatan interpretif. Penulis menggunakan hasil kajian literatur berupa jurnal dan buku yang memberikan dasar konseptual mengenai socio-preneur dan co-production systems sebagai pengembangan konsep new public governance yang dikenal dalam bidang ilmu administrasi publik maupun ilmu sosial lainnya secara luas.

\section{HASIL DAN PEMBAHASAN}




\section{Jurnal Ilmu Pemerintahan: Kajian Ilmu Pemerintahan dan Politik Daerah, 3 (2), Oktober 2018 - 127 \\ Evi Sukmayeti1) *, Vidya Yanti Utami²)}

Ida Wahyuni menjadi pelopor yang mendirikan Desa Setanggor yang kini dikenal sebagai Desa Wisata. Sebagai seorang socio-preneur yang melihat bahwa desanya memiliki sumberdaya yang strategis untuk memberikan pengalaman unik bagi wisatawan, Ida awalnya menemukan kesulitan dalam mengajak seluruh masyarakat Setanggor untuk bersama-sama mengembangkan desa mereka menjadi salah satu obyek desa wisata halal.

Dalam mencapai idealismenya agar masyarakat Setanggor bisa menjadikan apa yang mereka miliki di desa sendiri sebagai sumber kesejahteraan, ia dibantu dalam jaringan promosi persatuan travel di Indonesia, individu pemandu wisata dan intitusi seperti PT. ASDP Indonesia Ferry (Persero) mereka ikut membantu memberikan bantuan baik berupa finansial maupun non finansial. Sementara dalam aktivitasnya, Ida menyebutkan bahwa Pemerintah Kabupaten Lombok Tengah belum ada membantu apapun (Wawancara, 2017). Desa Setanggor dalam pandangan Ida memiliki potensi yang bernilai ekonomis berupa alam yang belum dikembangkan atau dikemas untuk memberikan pengalaman rekreatif, beberapa komunitas seniman dan kelompok kesenian yang terbiasa mengikuti even budaya bahkan memperoleh prestasi, kebiasaan dan ritual religius sebagai implikasi dari kehidupan masyarakat suku Sasak di sana serta bentuk-bentuk peralatan yang memiliki nilai sejarah dan patut untuk diketahui oleh orang-orang luar melalui kunjungan ke Setanggor.

Saat ini Desa Setanggor memiliki 11 Dusun. Dengan pengembangan menjadi desa wisata, 11 dusun tersebut disiapkan oleh Ida, komunitas dan masyarakatnya sebagai obyek wisata dengan konsep yang berbeda-beda yakni wisata budaya dan seni, wisata religi, wisata alam khususnya pertanian dan sebagainya. Dengan seringnya pengunjung hadir dan merasakan pengalaman melalui produk wisata yang disediakan oleh Setanggor dan warganya, maka desa ini kemudian menciptakan kesempatan ekonomi bagi seluruh warga.

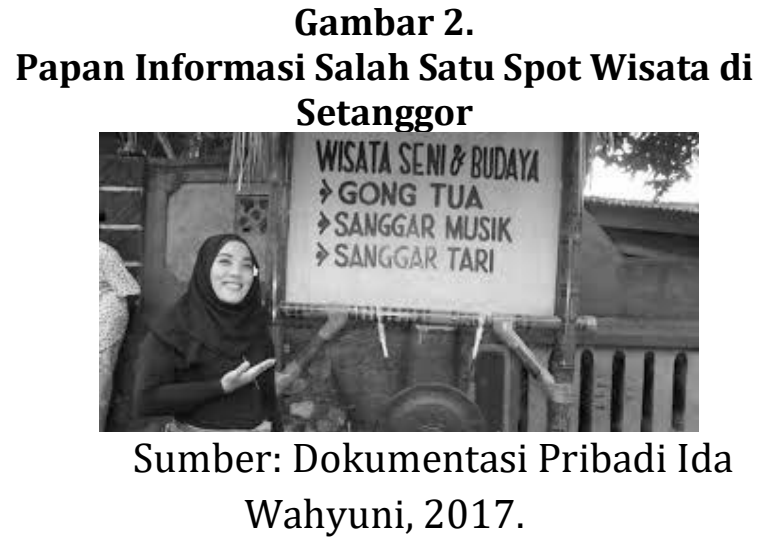

Dalam mencetuskan dibangunnya co-production system bagi pembangunan desa, Ida bertindak sebagai individu sociopreneur yang mandiri. Artinya ia tidak dengan sengaja menciptakan komunitas yang selanjutnya saling terhubung satu sama lain. Dengan bekal pembinaan yang ia lakukan, Desa Setanggor sebagai desa wisata berkembang dengan dibangun oleh banyak komunitas dan individu yang ada: seniman, warga biasa, pemandu wisata tempatan. Sementara jejaring yang terbentuk melibatkan pegiat media massa, penyedia jasa transportasi wisata, institusi swasta dan non-pemerintah lainnya.

Sementara itu di Lingkungan Banjar Selaparang yang merupakan salah satu daerah pemukiman penduduk di Kota Mataram, Lombok, Nusa Tenggara Barat adalah Aisyah, salah seorang socio- 


\section{Jurnal Ilmu Pemerintahan: Kajian Ilmu Pemerintahan dan Politik Daerah, 3(2), Oktober 2018-128 \\ Evi Sukmayeti1) *, Vidya Yanti Utami ${ }^{2}$ )}

preneur bangsa yang kiprahnya menginspirasi banyak pejuang perbaikan lingkungan, bergerak melalui Bank Sampah Nusa Tenggara Barat Mandiri (NTBM), lingkungan ini identik dengan pemukiman kumuh padat penduduk. Konsekuensinya secara fisik lingkungan pemukiman ini terlihat sumpek dan kotor. Aisyah tinggal di lingkungan tersebut.

\section{Gambar 3. \\ Kaitan Co-Production System Desa Wisata Setanggor dan Socio-preneur Mandiri}

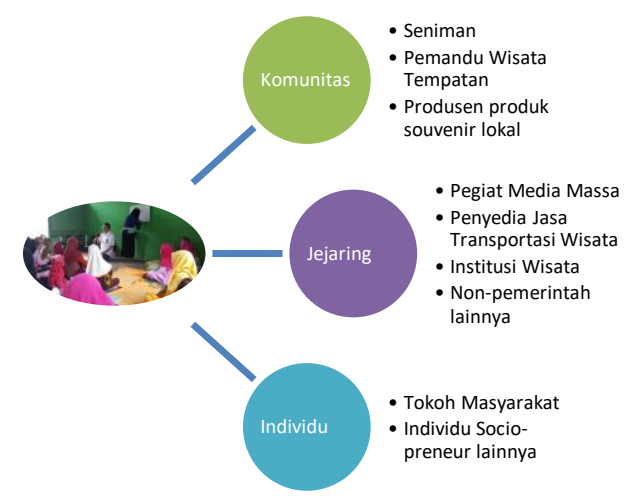

Awalnya Bank Sampah NTBM didirikan bersama temannya yang memiliki hobi melancong yang sama. Dulu ia sering bersepeda mengitari kawasan pulau Lombok. Ini menjadikan pengalamannya menyaksikan sampah yang berserakan dalam sepanjang perjalanannya kaya akan inspirasi bahwa ada sampah yang bisa jadi bahan baku atau sumberdaya yang jika mendapatkan sentuhan kreatif akan menciptakan nilai ekonomi yang lebih sekaligus menyelamatkan lingkungan. Akhirnya tahun 2011 ia mulai mendirikan Bank Sampah NTBM. Tujuan utamanya adalah bagaimana masyarakat paham akan nilai finanasial yang dapat dihasilkan dari sampah. Ia memiliki nasabah yang dididik bagaimana menyiakan sampah untuk bahan dasar daur ulang. Selanjutnya ia dan teman-temannya pendiri Bank Sampah NTBM berkreasi menciptakan produk bermanfaat dan menjualnya di pasaran. Dengan jaringan yang ia miliki, produkproduk tersebut direspon baik dan hasil penjualan produk disisihkannya untuk menggantikan tabungan sampah yang ia terima dari nasabah.

Dalam proses perkembangannya, melimpahnya pasokan bahan dasar yang disetorkan nasabah berhadapan dengan kenyataan bahwa sumberdaya manusia yang ia miliki dalam menciptakan produk sangat terbatas (Wawancara, 2016).

\section{Gambar 4.}

Aisyah di antara Setoran Nasabah.

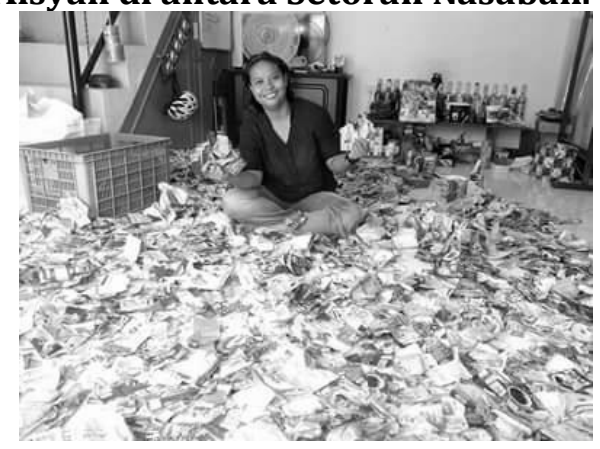

Sumber: Koleksi Dokumentasi Pribadi Aisyah Odist, 2016

Ketidakseimbangan antara banyaknya setoran sampah dan sedikitnya tenaga terampil untuk mendaur ulang, menciptakan kebutuhan bagi bank sampahnya untuk menyediakan tenaga kerja yang lebih banyak. Dibutuhkan pengrajin yang memiliki keterampilan untuk membuat berbagai produk yang biasa dicari oleh pasarnya. Akhirnya ia mulai mendidik nasabahnya sendiri untuk memproduksi berbagai plastic kemasan menjadi bahan stengah jadi, bahkan menjadi pemasok produk jadi yang ia tamping untuk dipasarkan lewat jaringannya. 


\section{Jurnal Ilmu Pemerintahan: Kajian Ilmu Pemerintahan dan Politik Daerah, 3 (2), \\ Oktober 2018 - 129 \\ Evi Sukmayeti1) *, Vidya Yanti Utami²)}

Gambar 5.

Salah satu pelatihan melipat kemasan bagi nasabah.

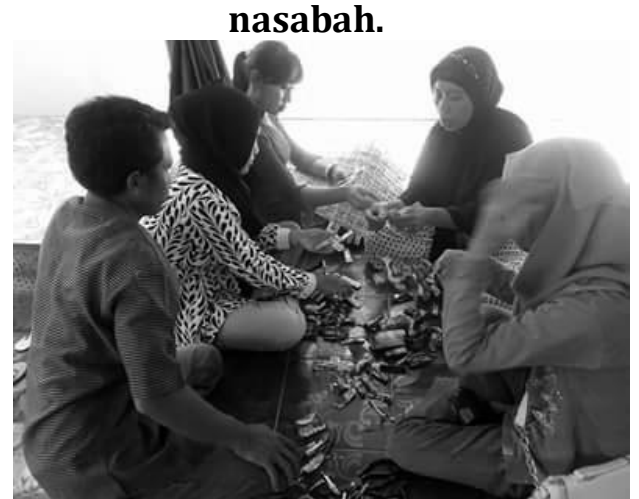

Sumber: Koleksi Dokumentasi Pribadi Aisyah Odist, 2016.

Nasabahnya tidak lagi hanya menjadi pemasok bahan dasar berupa sampah yang telah bersih dan siap olah, namun menjadi mitra produksi yang memasok bahan setengah jadi bahkan produk akhir. Semuanya sama-sama diapresiasi dengan tabungan dengan nominal yang ia sesuaikan berdasarkan nilai tambah ekonomis dari setiap bentuk setoran.

Pergaulannya yang luas, tidak hanya menyediakan komunitas pengrajin daur ulang, namun juga jejaring pasar yang baik.Ini menjadi sumberdaya yang penting bagi keberlanjutan aktivitasnya hingga sekarang. Bank Sampah NTBM memiliki tidak kurang dari 30 mitra kegiatan hingga 2016. Bank Sampah NTBM memiliki mitra bank sampah lain yang terbentuk dari pelatihan-pelatihan yang ia selenggarakan secara inisiatif maupun bentukan dari komunitas lain yang dimulai belakangan setelah NTBM sendiri. Tidak hanya komunitas, ia memiliki mitra sekaligus konsumen dari pihak swasta utama hotelhotel di Lombok dalam pengeloaan sampah hotel dan pasar bagi produk pupuk organic yang ia dan mitranya produsen.Ia sendiri mendapatkan banyak binaan dari lembaga luar negeri seperti
Jepang dalam tata cara pengolahan sampah organic maupun dari dalam negeri seperti dukungan materil melalui program pertanggung jawaban sosial perusahaan Perusahaan Listrik Negara (PLN). Dari sampah, Bank NTBM memiliki asset kegiatan berupa kantor dan showroom yang representative (Observasi, 2017). PLN menyumbangkan sarana transportasi mengingat mobilitas Aisyah yang sangat tinggi dalam memberikan pelatihan dan pembinaan kepada mitranya.

Dari Bank Sampah NTBM, selanjutnya Aisyah lebih jauh berpikir mengenai pengembangan nasabah dan pasar yang lebih luas. Lingkungan tempat tinggalnya pun kemudian menginspirasinya untuk mendukung idealism tersebut. Tahun 2016 lalu Bank Sampah NTB Mandiri hanya memfokuskan kegiatan mereka pada edukasi masyarakat tentang daur ulang sampah (Wawancara, 2016). Namun pada tahun 2017 ia mulai memotivasi masyarakat sekitar, yang tadinya hanya menjadi pemasok bahan mentah atau bahan dasar setengah jadi menjadi komunitas yang menjadi tempat belajar memperbaiki kualitas lingkungan hidup. Ia dan masyarakat Banjar Selaparang, Kota Tua Ampenan lalu merintis kampung wisata yang berbasis lingkungan atau yang mereka perkenalkan sebagai Kawis Krisant (Kampung Wisata Kreatif Sampah Terpadu). Di kampung tersebut, warga diajak berbenah, membersihkan, menyulap jadi indah serta menjamu tamu dengan pertunjukan seni sederhana yang bisa disediakan oleh warga. Sumberdayanya itak lupa ia hubungkan dengan bank sampah yang telah ia rintis. Berbagai alat yang digunakan atau bisa disaksikan di kampung tersebut berasal dari daur 


\section{Jurnal Ilmu Pemerintahan: Kajian Ilmu Pemerintahan dan Politik Daerah, 3(2), Oktober 2018-130 \\ Evi Sukmayeti1) *, Vidya Yanti Utami ${ }^{2)}$}

ulang sampah.Begitu pula berbagai macam souvenir yang dapat dibeli wisatawan adalah produk bank sampahnya sendiri. Ada tahap dimana permintaan pasar wisata Kawis Krisan lebih besar dari ketersediaan produk dan bahan bakunya. Oleh karenanya biasanya Aisyah menghubungi jaringan pemasok bahan baku sampah yang ia butuhkan. Begitu Seterusnya hingga saat ini, dimana inovasinya berhadapan dengan pengalaman bank sampah ketika mengalami kekurangan tenaga kreatif dan produksi dimana ia biasanya menciptakan sumberdaya manusia yang terampil dengan sampah atau di saat yang lain menghadapi bahwa produknya mulai bertambah dimana ia harus memperluas pasar salahsatunya melalui Kawis Krisant tersebut.

Setidaknya ada beberapa hal yang dapat dicermati dari aktivitas seorang socio-preneur Aisyah melalui Bank Sampah NTBM dan terutama adalah Kawis Krisant sebagai sistem co-production dalam persoalan lingkungan dan ekonomi warga. Pertama, Bank Sampah NTBM dibangun oleh sumberdaya personal atas dasar idealisme kebutuhan publik terhadap lingkungan yang bersih dan sehat dimana peran pemerintah daerah terutama di Kota Mataram belum mampu mengimbangi beban masalah lingkungan yang tercermin dari keberadaan sampah di banyak tempat terumata pemukiman. Aktivitasnya dapat diidentifikasi mulai dari proses perencanaan hingga tersedianya perubahan lingkungan yang signifykan di Kawis Krisant. Kawis Krisant sebagai bentuk sistem co-production menyediakan layanan publik bagi lingkungan itu sendiri dalam beberapa bentuk: lingkungan dan ekonomi (melalui aktivitas pariwisatanya). Sekalipun masih terlalu dini menilai dampak dari sistem yang bejalan di Kawis Krisant, setidaknya ada perubahan sosial masyarakat yang terkondisikan dengan statusnya kini yakni pola hidup bersih dan rapi masyarakat, terlatihnya warga untuk kreatif dan siap masuk dalam pergaulan yang lebih luas sebagai akibat dari rutinnya kunjungan wisatawan, dan secara ekonomi dimana warga dapat menjadi nasabah aktif bank sampah NTBM ataupun menjual produk penunjang lainnya yang memiliki nilai finansial bagi kehidupan mereka.

Kedua, efektifnya sistem coproduction di Kawis Krisant tidak lepas dari berjalannya peran socio-preneur seorang Aisyah yang mampu mengelola modal sosial masyarakat di lingkungan bank sampah, jaringan yang sangat terbuka sehingga proses inovasi berjalan terus menerus dan nilai ekonomi daur ulang sampah di jaringan pasar yang ia miliki atau bangun terus meningkat dari waktu ke waktu. Jika dibangun pemahaman sistematis mengenai co-production yang berkembang di Kawis Krisant, di dalam proses yang berjalan tersebut lebih dahulu dapat diidentifikasi eksistensi aktor socio-preneur. Ada motif keberlanjutan kesejahteraan komunitas dan jejaring bank sampah NTBM yang mendorong co-production system Kawis Krisant diciptakan berbasis wisata (dan) lingkungan.

Ketiga, jaringan Kawis Krisant dengan Bank Sampah NTB Mandiri, sekalipun dibangun oleh aktor yang sama, berjalan secara kemitraan dan efektif dikarenakan masing-masing pihak baik dalam komunitas, sebagai jaringan maupun individu partisipan memiliki hubungan timbal balik dalam berkontribusi. Kawis Krisant dengan komunitas warga 
Jurnal Ilmu Pemerintahan: Kajian Ilmu Pemerintahan dan Politik Daerah, 3 (2),

Oktober 2018 - 131

Evi Sukmayeti1) *, Vidya Yanti Utami²)

dan jejaringnya menciptakan pasar atau kebutuhan bagi produk dan aktivitas Bank Sampah NTBM. Hubungan tersebut memiliki latarbelakang sosial (dikarenakan aktor penggeraknya merupakan warga Kawis Krisant sendiri) dan latar belakang idealisme di balik berdirinya Bank Sampah NTBM sekalipun kemudian dampak peningkatan kesejahteraan warga, komunitas dan jaringan kedua institusi ini menjadi konsekuensi yang nyata.

Ida dan Aisyah mewakili sociopreneur sebagaimana dipahami dalam (Santosa, 2007) dimana keberadaannya harus berimplikasi pada perubahan sosial. Begitupula sejalan dengan konseptualisasi oleh (Dees dalam Listyorini, 2012) bahwa kedua aktor tersebut menunjukkan konsistensi dalam berkarya, melahirkan sejumlah inovasi dan konsisten dalam kegiatan sosial yang salah satunya berorientasi pada kesejahteraan masyarakat yang mereka targetkan.

Di Setanggor, nilai sosial yang semula menempatkan seni dan budaya sebagai aset budaya dan identitas semata, dikemas oleh Ida Wahyuni sebagai komoditas ekonomi dalam konteks wisata. Masyarakat tempatan secara otomatis menjadi aktor yang terlibat dalam bisnis wisata Setanggor. Selain sebagai pemiliki aset budaya dan identitas, masyarakat menjadi pelaku usaha dimana pertunjukan yang mereka suguhkan bagi wisatawan menjadi kegiatan ekonomi sampingan mereka disamping pertanian. Ida juga melakukan inovasi dalam kegiatannya seperti memperbaharui sistem pemasaran produk pertunjukan. Ia tidak hanya mengandalkan pola promosi konvensional, namun juga memahami dan memanfaatkan jaringan pemasaran wisata modern.

Dalam setting governansi publik Kawis Krisant, Aisyah mengubah nilai sosial yang memandang bahwa sampah menjadi materi akhir yang tidak memiliki nilai menjadi bernilai ekonomi dan lingkungan. Ia melibatkan masyarakat di sekitar tempat tinggalnya dan membangun jaringan di banyak lingkungan yang lain. Ia melakukan inovasi, tidak hanya pada bentuk bahan baku sampah, namun juga pada produk dan sistem pemasaran. Dengan wadah kegiatan Bank Sampah NTB Mandiri, ia memiliki nasabah yang menabung dalam bentuk olahan dasar sampah, yang kemudian dia produksi dan distribusikan ke pasar yang prospektif hingga luar negeri. Bahkan ia pun mengembangkan hilirisasi kegiatannya berupa kampung wisata dimana produk bank sampahnya juga menjadi komoditas bernilai ekonomi sebagai souvenir dan kegiatan yang dilakukan oleh pegawainya dalam mengolah sampah sebagai salah satu obyek wisata. 
Jurnal Ilmu Pemerintahan: Kajian Ilmu Pemerintahan dan Politik Daerah, 3(2),

Oktober 2018-132

Evi Sukmayeti ${ }^{1)}$, Vidya Yanti Utami ${ }^{2}$ )

Gambar 6.

Bagan Kaitan Sistem Co-production di Kawis Krisant dengan Socio-preneurship Bank Sampah NTBM.

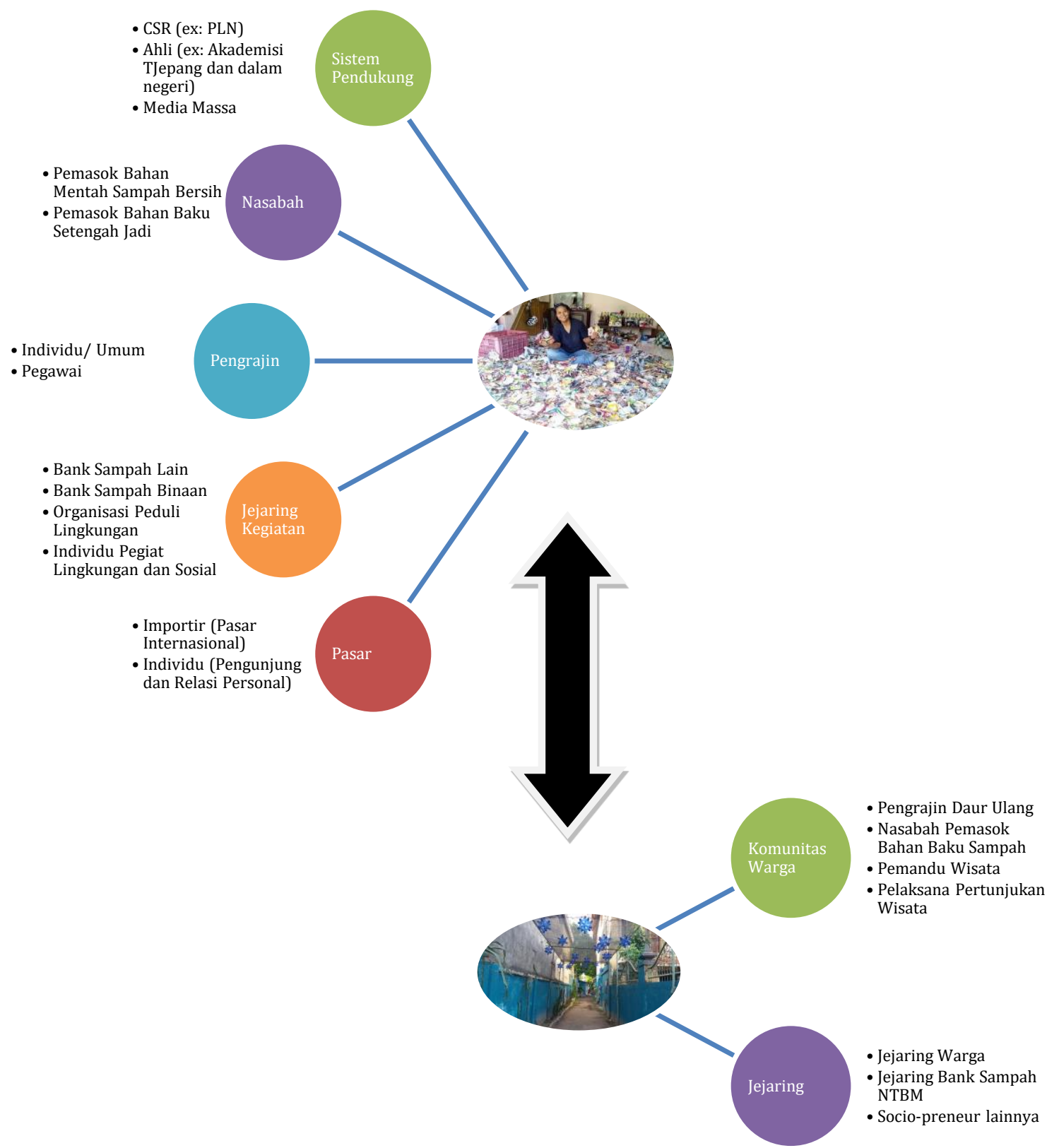

Copyright (C) 2018, JIP, ISSN: 2503-4685 (Print), ISSN: 2528-0724 (Online) 


\section{Jurnal Ilmu Pemerintahan: Kajian Ilmu Pemerintahan dan Politik Daerah, 3 (2), \\ Oktober 2018 - 133 \\ Evi Sukmayeti1) *, Vidya Yanti Utami²)}

\section{SIMPULAN DAN SARAN}

\subsection{Simpulan}

Desa Setanggor di Lombok Tengah dan Kawis Krisant di Kota Mataram adalah beberapa contoh hasil governansi publik yang menggunakan konsep sistem coproduction dimana komunitas dan masyarakat menyediakan sendiri layanan publik yang mandiri terlepas dari pemerintah yang selama ini dianggap paling efektif menyediakan fasilitas publik dan pihak ketiga swasta yang dipandang paling efisien dalam menjalankan peran yang sama. Baik Desa Setanggor maupun Kawis Krisant, keduanya berkembang tidak lepas dari peran socio-preneur yang berjalan secara mandiri maupun terkoneksi dengan sistem co-production lainnya. Keduanya berjalan efektif dengan mengandalkan kontribusi modal sosial yang ada di sekitar mereka, saling timbal balik, dan secara berkelanjutan memproduksi barang dan jasa yang bernilai ekonomis sehingga kesejahteraan sosial komunitas dan warga dapat dilihat sebagai dampaknya.

\subsection{Saran}

Model governansi publik dengan konsep co-production system ini harus diintrodusir secara luas. Potensi sociopreneur dengan motivasi dan inovasi mungkin saja tersedia di tengah masyarakat Indonesia saat ini. Sehingga pengalaman kedua socio-preneur dan pola mereka menjaga agar sistem coproduction tersebut agar tetap berjalan, dapat menjadi alternatif untuk diikuti. Untuk tahap yang lebih lanjut, antar sistem co-production pun dapat membangun jaringan kerjasama yang saling membutuhkan bahkan secara solid saling ketergantungan seperti halnya yang dirintis oleh Aisyah.

\section{DAFTAR PUSTAKA}

Bekkers, V. J. J. M., Tummers, L. G., \& Vooberg, W. H. (2013). From Public Innovation To Social Innovation in the Public Sector: A Literature Review of Relevant Drivers And Barriers. Roterdam: Erasmus University Rotterdam. Retrieved from http://lipse.org/userfiles/uploads/F rom public innovation to social innovation in the public sector.pdf

Bernard, H. R. (2006). Research Methods in Anthropology: Qualitative and Quantitative Approach (4th ed.). USA: Altamira Press. Retrieved from http://www.cycledoctoralfactec.com /uploads/7/9/0/7/7907144/\%5Bh. _russell_bernard\%5D_research_meth ods_in_anthropol_bokos-z1_1_.pdf

Dees, J. G. (2001). The Meaning of Social Entrepreneurship. Kansas: Kauffman Foundation. Retrieved from https://centers.fuqua.duke.edu/case /wpcontent/uploads/sites/7/2015/03/ Article_Dees_MeaningofSocialEntrep reneurship_2001.pdf

Flick, U. (2013). The SAGE Handbook of Qualitative Data Analysis. Retrieved from http://www.ewi-psy.fuberlin.de/einrichtungen/arbeitsbere iche/qualitative_sozial_bildungsforschung/Medien/58869_ Flick_The_SAGE_HB_of_Qualitative_ Data_Analysis_Chapter1_mappingthe-field.pdf.

Horne, M., \& Shirley, T. (2009). Coproductioin public services:a new partnership with citizens. Retrieved from https://www.google.co.id/url?sa=t\& $\mathrm{rct}=\mathrm{j} \& \mathrm{q}=\& \mathrm{esrc}=\mathrm{s} \&$ source $=$ web $\& \mathrm{~cd}=1$ \&ved=2ahUKEwjZ1- 
Jurnal Ilmu Pemerintahan: Kajian Ilmu Pemerintahan dan Politik Daerah, 3(2),

Oktober 2018- 134

Evi Sukmayeti1) *, Vidya Yanti Utami2)

fw5pfeAhWGvY8KHQFiCp4QFjAAeg

QICRAC\&url=http\%3A\%2F\%2Fweba rchive.nationalarchives.gov.uk\%2F\% 2B\%2Fhttp $\% 3 \mathrm{~A} \% 2 \mathrm{Fwww}$. cabinetoff ice.gov.uk\%2Fmedia\%2F $207033 \% 2$ Fpublic_services_coproduction.pdf\&usg=AOvVaw3Lr89E loSiBKYKXKEuaE_A

Hulgard, L. (2010). Discoures of Social Entrepreneurship - Variations of the same theme? Denmark: Roskilde University. Retrieved from http://base.socioeco.org/docs/wp_1 0-01_hulg_rd_web_.pdf

Listyorini, H. (2012). Komponen dan Dampak Sosial Entrepreneurship Dalam Upaya Revitalisasi Budaya dan Industri Batik Lasem, Kabupaten Rembang. Jurnal Dinamika Kepariwisataan, Vol. XI No, 48-57. Retrieved from https://www.unisbank.ac.id/ojs/ind ex.php/pdk1/article/download/172 $0 / 634$

Pratikno. (2007). Mengelola Dinamika Politik dan Jejaring Kepemerintahan Daerah: Kemitraan, Partisipasi dan Pelayanan Publik. Yogyakarta: Program S2 Politik Lokal dan Otonomi Daerah Universitas Gadjah Mada. Retrieved from http://www.academia.edu/1156713 /Mengelola_Dinamika_Politik_dan_Jej aring_Pemerintahan_Kemitraan_Part isipasi_dan_Pelayanan_Publik

Putra, F. (2012). New Public Governance. Malang: UB Press. Retrieved from http://bookstore.ub.ac.id/shop/ilmu -administrasi/new-publicgovernance/

Sanrego, Y. D., \& Taufik, M. (2016). Fiqih Tamkin (Fiqih Pemberdayaan). Jakarta: Qisthi Press. Retrieved from http://wisatabuku.com/fiqihtamkin/

Santosa, S. (2007). Peran Social Entrepreneurship dalam
Pembangunan. Retrieved July 18, 2018, from http://nurrahmanarif.wordpress.co $\mathrm{m} /$ socialentrepreneurship

Saragih, R. (2017). Membangun Usaha Kreatif, Inovatif Dan Bermanfaat Melalui Penerapan Kewirausahaan Sosial. Jurnal Kewirausahaan, Vol. 3 No. Retrieved from https://media.neliti.com/media/pub lications/223703-membangunusaha-kreatif-inovatif-dan-ber.pdf

Sicilia, M. (2016). Public Services Management and Co-Production In Multi-Level Governance Settings. International Review of Administrative Sciences, Vol. $82 \mathrm{No}$, 827. Retrieved from http://journals.sagepub.com/doi/ab s/10.1177/0020852314566008

World Economic Forum. (2017). The Inclusive Growth and Development. Retrieved from www3.weforum.org/docs/WEF_For um_IncGrwth_2017.pdf\%0A\%0A

Yaumiddin, U. K. (2013). Kewirausahaan Sosial Dan Tanggung Jawab Sosial Perusahaan: Tantangan Sinergi MultiSektor Dan Multi-Dimensi. Jurnal Ekonomi Dan Pembangunan, Vol 21, No. Retrieved from https://media.neliti.com/.../77596ID-kewirausahaan-sosial-dantanggung-jawab.pdf\%0A\%0A

Zakaria, Y. R. (2004). Merebut Negara, Beberapa Catatan Reflektif tentang Upaya-upaya pengakuan, Pengembalian, dan Pemulihan Otonomi Desa. (1st ed.). Yogyakarta: LAPERA Pustaka Utama bekerjasama dengan KARSA. Retrieved from https://books.google.co.id/books?id =fX1xAAAAMAAJ\&q=Zakaria, + Yando $+\mathrm{R}+(2004) .+$ Merebut+Negara, + Bebe rapa+Catatan+Reflektif+tentang+Up aya-

upaya+pengakuan,+Pengembalian,+ 
Jurnal Ilmu Pemerintahan: Kajian Ilmu Pemerintahan dan Politik Daerah, 3 (2), Oktober 2018 - 135

Evi Sukmayeti1) *, Vidya Yanti Utami ${ }^{2)}$

dan+Pemulihan+Otonomi+Desa.+Yo

gyakarta:+LAPERA+Pustaka+Utama+ bekerjasama+dengan+KARSA.\&dq=Z

akaria,+Yando+R+(2004).+Merebut+

Negara,+Beberapa+Catatan+Reflektif

+tentang+Upaya-

upaya+pengakuan,+Pengembalian,+

dan+Pemulihan+Otonomi+Desa.+Yo

gyakarta:+LAPERA+Pustaka+Utama+

bekerjasama+dengan+KARSA.\&hl=id

$\&$ sa $=$ X\&ved $=0$ ahUKEwjlgNbA45feAh

WLN48KHajaCbgQ6AEIJzAA

\section{Profil Singkat Penulis}

Evi Sukmayeti, lahir di Pekanbaru, 1 Agustus 1982; menyelesaikan studi S1(2000-2004) dan S2 (2006-2008) pada Jurusan Ilmu Administrasi Negara Universitas Gadjah Mada; saat ini mengabdi pada Program Studi Ilmu Administrasi Negara Sekolah Tinggi Ilmu Administrasi (STIA) Mataram, Nusa Tenggara Barat.

Vidya Yanti Utami, lahir di Gerung, 31 Agustus 1993; menyelesaikan studi S1(2011-2015) dan S2 (2015-2017) pada Jurusan Ilmu Administrasi Publik Universitas Brawijaya; saat ini mengabdi pada Program Studi Ilmu Administrasi Negara Sekolah Tinggi Ilmu Administrasi (STIA) Mataram, Nusa Tenggara Barat 
